\title{
HOW DO EMERGING MULTINATIONALS CONFIGURE POLITICAL CONNECTIONS ACROSS INSTITUTIONAL CONTEXTS?
}

\author{
Dr Liang Chen* \\ School of Business, Management and Economics \\ University of Sussex, Brighton, UK \\ Telephone: (+44) 7572477149 \\ Email: liang.chen@sussex.ac.uk \\ Dr Yi Li \\ Discipline of International Business, \\ The University of Sydney, Sydney, Australia \\ Telephone: (+61) 286275935 \\ Email: yi.li2@sydney.edu.au \\ Dr Di Fan \\ School of Management, \\ Curtin Business School, \\ Curtin University, Perth, Australia \\ Telephone: (+61 8) 92667895 \\ Email: david.fan@curtin.edu.au
}

*Corresponding author. All three authors make equal contributions.

Running head: Configure political connections across institutional contexts

This is the author manuscript accepted for publication and has undergone full peer review but has not been through the copyediting, typesetting, pagination and proofreading process, which may lead to differences between this version and the Version of Record. Please cite this article as doi: $10.1002 / \mathrm{gsj} .1187$

This article is protected by copyright. All rights reserved. 


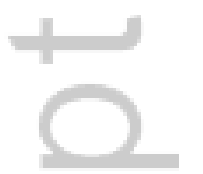

4 


\section{HOW DO EMERGING MULTINATIONALS CONFIGURE POLITICAL CONNECTIONS ACROSS INSTITUTIONAL CONTEXTS?}

\section{Research summary}

Forming informal ties with political agents is viewed as a viable strategy for multinational enterprises seeking to enter emerging countries. Less is known about the conditions under which political connection is most helpful for firms dealing with crossborder institutional distance. We discuss the distinctive mechanisms through which emerging multinationals may benefit from both home and host political connections. Based on the strategy tripod perspective, we postulate that the importance of different types of connections depends on the overall configurations of a firm's resources and industry characteristics, and these may change with institutional distance. Our analysis of a sample of Chinese high-tech manufacturing firms yields new insights into political connections, institutional distance and the strategy tripod perspective.

\section{Managerial summary}

Political connections play an important role in firms' international expansion. In this study, we consider the importance of home political connections and host political connections in overcoming institutional barriers to foreign entry. We show that this importance varies, depending on firms' resource base and industry dynamics, and it may switch from a useful asset to a dispensable one under certain circumstances. We reach our conclusion from an analysis of Chinese high-tech manufacturing firms' foreign direct investment.

This article is protected by copyright. All rights reserved. 
Keywords: political connection, institutional distance, the strategy tripod perspective, fuzzyset analysis, emerging multinationals

This article is protected by copyright. All rights reserved. 


\section{INTRODUCTION}

Institutional distance has been of lasting interest to international business (IB) scholars, since it summarizes "the barrier to international operations arising from discrimination by government, by consumers, and by suppliers" (Hymer, 1976: 34). Some argue that "international management is management of distance" (Zaheer, Schomaker, and Nachum, 2012: 19). While institutional distance by and large deters foreign investors (Berry, Guillen, and Zhou, 2010), why and how multinational enterprises (MNEs) can overcome distanceinduced "costs of doing business" or "liability of foreignness" has become one of the big questions in IB that defines its disciplinary distinctiveness (Peng, 2004; Zaheer, 1995). Differences in formal and informal institutions pose a particular barrier to the global expansion of emerging multinationals (EMNEs), which are already constrained by their inadequate resources and market-based capabilities (Peng, 2012).

A promising explanation of EMNEs' global strategy lies in the institution-based view of strategy (Peng et al., 2009). Research on advanced-country MNEs (AMNEs) suggests that they rely upon political connections - notably managers' interpersonal ties with public officials at various administration levels and from different branches of the government when venturing into emerging economies, and this is in reaction to the salient differences in the institutional environment (Li, Poppo, and Zhou, 2008; Luo, 2001). It is conceivable that similar strategies may be employed by EMNEs, which can arguably derive home-country based advantages from familiarity with such strategies in many emerging markets (Peng and Luo, 2000; Shi, Markóczy, and Stan, 2014). However, IB research has yet to explore whether and how political connections with the home and host authorities help EMNEs address 
institutional differences when entering foreign markets. Recent political connection literature lays strong emphasis on its contingent value (Sun, Mellahi, and Wright, 2012). Whether political connections are of use may depend on the type of networks (Sun et al., 2015) and intraorganizational and environmental factors (Sun et al., 2012). One example is that firms' ownership ties with the home government could impair their legitimacy in certain foreign countries (Meyer et al., 2014). Conjoining the inquiries of distance and political connections offers various opportunities to extend the literature. First and foremost, it begs these questions: 1) whether the efficacy of political connections in overcoming institutional differences depends on other factors known to affect EMNEs' international expansion; and 2) how the importance of certain connections changes with institutional distance.

In this paper, we elucidate whether, and under what conditions, managers' personal connections with the home and host government facilitate EMNEs' expansion to institutionally distant countries. We focus on the level of using political connections (Luo, 2003), rather than the process or structure of networking per se, or its heterogeneous types (cf. Sun et al., 2015). The use of connections reflects managers' desire to rely on networking and its perceived value in responding to organizational needs and environmental dynamics in the particular context. Given that political networking incurs significant cost and its effect depends largely on the structure of the institutional setting (Brockman, Rui, and Zou, 2013; Choi, Jia, and Lu, 2015), we view this non-market strategy as firms' strategic response to potential frictions in the environment in which they operate or aspire to operate (Sojli and Tham, 2017), in line with the institution-based view. Specifically, we examine the importance of political connections during the early process of entry, where institutional differences are 
arguably the most salient. To address the first question, we employ the strategy tripod perspective and fuzzy-set analysis to explore how resource-based and industry-based factors may complement political connections for EMNEs to venture in high-distance countries (we refer to 'institutional distance' hereafter). To answer the second question, we compare the configurations of strategy tripod factors in high-distance and low-distance countries.

We contribute to the literature in three respects. First, we advance the political connections research in the non-market strategy literature (Mellahi et al., 2016), which has focused predominantly on political connections in domestic contexts (Haveman et al., 2017; Shi et al., 2014). While recent studies examine the effect of home country and foreign political connections on firms' outward internationalization (Du and Luo, 2016; Sojli and Tham, 2017), what remain underexplored are the complementary conditions under which political networking is best suited to overcome institutional barriers to foreign entry, and can best help EMNEs take hold in distant countries. We reveal that high-distance investments are associated with the use of different types of connections, depending on the gestalts of firms' resource base and industry dynamics. Rather than assuming political connections as a universal asset for internationalizing firms, we show that, in certain cases, the utility of nonmarket strategy changes across institutional contexts. Second, we contribute to the distance literature. While there is consensus that institutional distance generally poses significant challenges to MNEs, a meaningful question remains unanswered as to why some MNEs, and particularly EMNEs, are not constrained by institutional distance. Therefore, we contrast our study with the conventional approach, and treat institutional distance as the outcome variable. Extant research pays insufficient attention to low-distance investments, which presumably 
incur negligible costs due to the linear effect of distance embedded in the regression approach (Gaur and Lu, 2007; Shenkar, 2001). Our analysis points to asymmetric causality, in that investment in low-distance countries does not constitute simply a mirror image of configurations associated with high-distance investments. Thirdly, we contribute to the strategy tripod literature. The essence of the strategy tripod perspective is to account for interactions of the three legs of the tripod. A regression-based approach has inhibited previous studies from unravelling this intricacy. Our set-theoretic design makes this paper among the very first attempts to test and advance the strategy tripod perspective as a whole.

\section{THEORETICAL BASIS}

\section{Institutional distance}

At the very foundation of IB lies the assumption that MNEs operate at a disadvantage relative to domestic firms (Hymer, 1976). This liability of foreignness emanates largely from crossnational variations in the institutional environment (Xu and Shenkar, 2002; Zhou and Guillen, 2016). Institutions refer to humanly devised structures guiding and constraining human interactions (North, 1990), including "political institutions such as the regime type, the national structure of policy-making and the judicial system, economic institutions such as the structure of the national factor markets and the terms of access to international factors of production and socio-cultural factors such as informal norms, customs, mores and religions" (Mudambi and Navarra, 2002: 638). Institutional economists posit that the degree of dissimilarity between institutions in the home and host country determines the level of uncertainty for MNEs when engaging with local political agents, and raises hurdle rates of return (Mudambi and Navarra, 2002). This uncertainty is intertwined with unfamiliarity 
hazards, i.e., information asymmetry arising from the lack of knowledge of the host country, and discrimination hazards, i.e., discriminatory treatment by host country stakeholders (Eden and Miller, 2004). Thus, the liability of foreignness is not confined to costs and legal burdens exclusive to foreign firms; it also entails institutional benefits denied to outsiders, including government subsidies, favorable policy treatments and exclusive contract arrangements. The probability of survival is lower when MNEs have to overcome higher institutional distance between the home and host country (Gaur and Lu, 2007), and thus they tend to refrain from investing in institutionally distant markets (Berry, Guillen, and Zhou, 2010).

Undoubtedly the construct of institutional distance has significantly improved our understanding of FDI. Empirical research sheds light on how institutional distance - as an independent, exogenous factor - influences MNEs' global strategies, including foreign entry, country selection, entry mode and ownership level, and its restrictive role is well documented (Berry et al., 2010; Zhou and Guillen, 2016). However, it leaves an intriguing question underexplored as to why some MNEs can overcome high institutional distance. The question is especially perplexing for two reasons. First, research suggests that costs stemming from institutional differences may accelerate at higher levels of the dyadic distance (Gaur and Lu, 2007). Disproportionate challenges are implied when MNEs expand to host countries far removed in institutional terms from the home environment. Second, latecomer EMNEs rarely possess significantly superior technological and managerial resources (Peng, 2012). Nor do they necessarily have stronger non-market competence over AMNEs in overcoming institutional distance (Cuervo-Cazurra and Genc, 2011). The recent global catch-up by EMNEs thus poses greater challenges to the conventional wisdom. We suggest that, above 
and beyond the established, independent role of institutional distance, new insights would accrue from describing those EMNEs that are successfully overcoming institutional distance.

It is theorized that institutional distance drives liabilities of foreignness in a linear fashion: the larger the institutional distance to overcome, the greater the liability of foreignness, and the more difficulty and pressures the MNE must deal with (Eden and Miller, 2004; Zhou and Guillen, 2016). This linearity is reinforced - rather than tested - by the mechanics of regression commonly used in previous research. One implication is that, when institutional distance is sufficiently low, the difficulties for MNEs to overcome, in addition to what domestic firms have to bear, become negligible (Gaur and $\mathrm{Lu}, 2007$ ). One might reason that investing in institutionally proximate countries may not be significantly different to domestic venturing, in that existing organizational practices and knowledge are readily transferable to a neighboring market. This is often assumed - by researchers and by practitioners alike - rather than challenged (Shenkar, 2001). However, case studies suggest that this is an illusion, and managers often fall into a confidence trap by underestimating the complexity of low-distance investments (O'Grady and Lane, 1996). In fact, similarities and differences between the home and host country have distinct impacts on internationalization decisions. We therefore posit that, not only would there be threshold requirements for lowdistance FDI, these investments may also rely upon distinct configurations of internal and external factors, once we relax the assumption of linearity of the distance effect.

\section{Political connections}

Connecting with political agents has been recognized as one of the generic strategies for firms in dealing with institutional pressures, because it creates various values, including 
“preferential treatment by government-owned enterprises (such as banks or raw material producers), lighter taxation, preferential treatment in competition for government contracts, relaxed regulatory oversight of the company in question, or stiffer regulatory oversight of its rivals, and many other forms" (Faccio, 2006: 369). In this paper, we define political connections as managers' social and relational ties with public officials at various administration levels and from different branches of the government. This definition is closely in line with previous studies (Li and Zhang, 2007; Luo, 2001; Peng and Luo, 2000), but broader than those focusing on political affiliations (e.g., Cui and Jiang, 2012). Managers act as boundary spanners to engage with external agents upon which their firms depend, including government officials. Research suggests that such political connections are widely employed by domestic firms in emerging economies, particularly China (Li and Zhang, 2007; Peng and Luo, 2000). Given the government's active role in allocating resources in the strategic factor market, it becomes imperative for Chinese firms to build informal ties with numerous government agencies in pursuit of survival and growth (Wu, Li, and $\mathrm{Li}, 2012)$.

For FDI, political connections may exert an even stronger influence on MNEs' strategic activities, considering the monopoly of power exercised by governments over MNEs and the former's control of location-specific advantages (Boddewyn, 1988). MNEs may derive three main benefits from ties with home and host governments. First, the home country government controls critical resources in the competitive environment. Emerging economies are characterized by imperfect domestic factor markets, where the government has discretion over distributing bank loans, subsidies and favorable regulations, particularly in relation to FDI (Buckley et al., 2007; Luo, Xue, and Han, 2010). Research shows that political 
connections in terms of home government ownership grant easier access to financial aid, preferential incentives, administrative assistance and potential bailout, in support of domestic firms' international expansion (Cui and Jiang, 2012). In the event of conflict with the host country, these firms are also well-placed to mobilize the home government to protect their overseas investments (Duanmu, 2014). Second, host country political elites confer political legitimacy on foreign firms. The lack of legitimacy is considered a major source of uncertainty for MNEs. Political connections signal the endorsement and acceptance by host government officials, which provides a "social license" to operate and increases MNEs' credibility in the eyes of the public (Luo, 2001). Third, both home and host country governments offer crucial access to regulatory and industrial information. Well-connected firms enjoy lead knowledge of upcoming laws, regulations and outward investment policies through ties with home officials, and are poised to seize the strategic opportunities opened up by policy changes (Shi et al., 2014). In China, the information as to which countries and industries will be preferred by the government and included in the next Guidance Catalogue of Countries and Industries for Overseas Investment may be but one example (Lu et al., 2014). In the host country, information passed on through political channels is also important for outsiders in reducing environmental uncertainty (Johanson and Vahlne, 2009). Exploiting information asymmetry allows MNEs to derive competitive advantages from unnatural market imperfections (Boddewyn and Brewer, 1994). These advantages only accrue to politically connected firms, whether in the home or host countries.

However, caution needs to be exercised, since political connections do not come without a price. Dependence on external agents invites the risk of losing the firm's autonomy 
(Mellahi et al., 2016). Firms are exposed to pressures of aligning resource allocation with the political agents' own agendas, and there is a need to develop separate strategies to manage contradictory and potentially predatory demands from these agents (Dieleman and Boddewyn, 2012). IB research implies that beneficial political connections could turn into a liability as the institutional context changes - either across the border (Meyer et al., 2014) or over the progression of economic liberalization (Sun, Mellahi, and Thun, 2010). Partnering with the wrong agents at the wrong time may even incur significant social and economic costs for the MNE (Siegel, 2007). From managerial perspectives, utilizing political connections to penetrate a foreign market is an endogenous decision, taking into account the expected returns and costs from developing and maintaining the ties (Luo, 2003).

\section{The strategy tripod perspective}

Traditionally, the explanation of firms' strategy rests upon two dominant theoretical foundations. The industry-based view posits that the conditions with the industry in which a firm operates determine strategies (Porter, 1980). The resource-based view complements this proposition by attributing within-industry variations in firm strategy to firm-specific resources (Barney, 1991). Nevertheless, IB research, in its attempts to understand firms' global strategy, often assigns primacy to the wider context of competition, at home or abroad. This raises appreciation that institutions - the "rules of the game" by which competition is organized (North, 1990) - matter in shaping firm strategy. The institution-based view is particularly germane in explaining the internationalization of EMNEs, as it brings to the forefront some of the distinctive characteristics of the institutional environment from which they originate. For instance, the rise of Chinese MNEs has drawn much attention to the 
supportive role of home country governments behind firms' internationalization (Lu et al., 2014; Luo et al., 2010) and the mechanisms through which connections with the home country government may influence foreign entry (Cui and Jiang, 2012; Meyer et al., 2014).

The term 'strategy tripod' is coined to highlight the importance of combining the three theoretical strands in search of an integrative platform upon which further explorations can be sought (Peng et al., 2009). While it seems established that the industry-based, resource-based and institution-based views each individually account for a non-trivial portion of variance in EMNEs' global strategy (Wang et al., 2012), the simultaneous examination of their independent, marginal roles is by no means the full mission of the strategy tripod. How the three legs interact to shape firms' global strategy represents the central inquiry which the integrative perspective seeks to address. This is predicated on the argument that firms' strategic considerations are holistic in nature, reflected in the constellation of interdependent factors. Yet the current empirical research has at best shed light on the interactions of two legs out of three (Lu, Liu, and Wang, 2011; Meyer et al., 2009). Given the equivocal findings of the EMNE literature on political connections (Meyer et al., 2014), researchers have called for contingency explanations (Li et al., 2008; Sun et al., 2012). Some suggest that the desire to establish and exploit, and the value of political connections, are dependent on internal factors, such as organizational needs, and external factors, such as industry dynamics (Luo, 2003; Park and Luo, 2001). From a holistic perspective, we identify the strategy tripod factors that may help EMNEs overcome institutional distance.

Institution-based view - political connections. We position political connections as the institution-based leg of the strategy tripod. While some consider political connections to 
be firms' network resources and social capital (Peng and Luo, 2000), we contend that political networking represents a series of proactive strategic attempts to engage with institutionally embedded agents in pursuit of economic and social return (Luo, 2003). The extent to which political networking is attempted and utilized depends on managers' evaluation of the expected return and costs in response to the external institutional structures (Choi et al., 2015; Sojli and Tham, 2017). In this study, we focus on connections with both home and host government agents. IB research thus far suggests that network linkages in the host country can moderate the negative role of institutional differences faced by MNEs, and MNEs having ties with the home government are less constrained by unfavorable host institutions (Duanmu, 2014). Firms venturing into a distant country may benefit more from connections than do those entering a proximate one, because of the significant degree of information asymmetry and lack of legitimacy arising from institutional differences.

Therefore, we posit that connections with the home and host government agents may be one of the key reasons behind EMNEs' success in overcoming institutional distance.

Resource-based view $-R \& D$ commitment and internationalization experience. It is widely argued that EMNEs exploit and/or seek to gain unique resources in foreign expansion (Guillén and Garcia-Canal, 2009). Whilst received wisdom suggests that the effect of political connections is weakened by the firm's resources and capabilities (Zhu and Chung, 2014), we contend that resources and political connections are not necessarily substitutive, and they may exhibit more complex relationships. In this study, we focus on two important resources for EMNEs, namely, $R \& D$ commitment and internationalization experience. 
$R \& D$ commitment. IB theory posits that firm-specific intangible assets can compensate for liabilities of foreignness when MNEs seek rents overseas (Zaheer, 1995). While R\&D expenditure and intensity may arguably be less important for EMNEs' international expansion in general, $R \& D$ activities are in every respect a crucial way for technology firms to enhance competitive advantages in the international market. R\&D activities reflect a firm's commitment to innovation, and its competence in providing product application solutions, technical training and maintenance services, as well as catering for new customers' needs ( $\mathrm{Li}$ and Atuahene-Gima, 2002). Commitment to innovation may motivate EMNEs to engage in distant countries, since opportunities for capability upgrading can justify the extra costs that firms have to bear. It appears that R\&D-intensive firms are less reliant on political agents' support (Zhu and Chung, 2014). However, host country governments are often concerned with potential threats that R\&D-intensive MNEs may pose, including technology leakage and loss of national competitiveness (Globerman and Shapiro, 2009), making political networking an even more effective channel for attaining legitimacy. Moreover, home country governments aiming for globally competitive industries may support R\&D-intensive domestic firms' efforts to venture or acquire knowledge abroad. These unsettled arguments imply more complex relationships.

Internationalization experience. Knowledge about how to internationalize and operate in foreign markets cannot be easily acquired; rather, it may have to be gained through direct experience (Johanson and Vahlne, 1977). Experienced firms develop routines and processes to estimate costs and returns, and to evaluate and meet the needs of foreign stakeholders (Erramilli, 1991). EMNEs are no exception. By entering and operating in distant countries, 
EMNEs learn to cater for formal and informal institutional differences in a foreign territory (Cui, Li, and Li, 2013). The combination of the countries in which an EMNE has accumulated operational experience determines its capacity to overcome institutional distance (Zhou and Guillén, 2015). However, a dilemma arises that, while internationally inexperienced firms suffer most from the lack of legitimacy, and thus are more willing to engage in political networking, their ability to identify and deploy the right agent in an unfamiliar environment may be constrained by experience of internationalization. In addition, whether experienced or less experienced firms are more reliant on home political connections to acquire state support and informational advantages remains unclear and underexplored.

Industry-based view - global environmental munificence and dynamism. The industry-based view posits that firms' international expansion strategy is driven by the degree of industrial competition that firms face (Boter and Holmquist, 1996). Competitive dynamics affect firms' performance prospects, which may increase or decrease their willingness to take on additional challenges, e.g., institutional distance, unless with the aid of superior resources or political connections (Li, Zhou, and Shao, 2009; Luo, 2003). To account for industry factors, we focus on two global environmental conditions - environmental munificence (EM) and environmental dynamism (ED) - since modern MNEs are nested in industries traversing different countries (Nielsen and Nielsen, 2010). A munificent environment has features of abundant resources and capacity to support sustained growth (Dess and Beard, 1984). Abundant resources attenuate competition intensity, and allow firms to pursue goals other than survival (Castrogiovanni, 1991). While EMNEs' international expansion may be constrained by institutional differences and liabilities of foreignness, environmental 
munificence increases their chances of survival in a distant market where they can aim for growth by exploiting existing firm-specific advantages or tapping into new knowledge sources the environment affords. It is reasonable to envisage that home country governments may be particularly keen to encourage domestic firms in munificent industries to venture abroad and seize the growth opportunities. Hence industrial characteristics may have implications for the effect of home political networking. Conversely, a munificent industry may have more room for foreign investors and additional productive capacity, so that EMNEs will rely less on host political connections to overcome entry barriers.

A dynamic environment is characterized by rapid and unpredictable changes in technology, market demand, consumer taste and competitive landscape (Lumpkin and Dess, 1995). It creates a need for firms to engage constantly in innovation in order to maintain a competitive position (Miller and Friesen, 1983). While dynamic marketplaces provide more opportunities for EMNEs to access new technology, marketing solutions, managerial practice and organizational design, frequent but irregular changes make it difficult to predict future states accurately. Whether environmental dynamism enables or inhibits EMNEs' expansion to distant countries may be related to other factors, such as firm-specific resources and political strategy. One might argue that dynamic environment requires firms to devote resources to product innovation and process adaptation, as opposed to non-market strategies. But it is equally conceivable that host political networking may alleviate stakeholders' concerns that EMNEs are intended to source knowledge and outcompete domestic firms in this dynamic market (Meyer et al., 2014). Both home and host political connections may also help firms acquire informational advantages in regard to industrial regulation, which are 
particularly beneficial for predicting future environmental states in a turbulent market. Next, we further explore complementarities of these strategy tripod factors using fuzzy-set analysis.

\section{METHODS}

\section{Sample and data}

As fast-growing players with institutionally diversified FDIs, Chinese MNEs are likely to rely on political connections, given the long tradition of using social ties to coordinate transactions at home (Li et al., 2009). Of these, we chose high-tech firms for three reasons. First, the Chinese government views technology industries as strategically important, and it has an intention to be active in supporting high-tech firm growth ( $\mathrm{Li}$ and Atuahene-Gima, 2002). Second, high-tech firms from emerging countries do possess a certain degree of technological know-how, driving them to catch up with Western counterparts on R\&D (Guillén and Garcia-Canal, 2009). Third, because of concerns over technology leakage, hightech firms face distinct liabilities of foreignness in less-developed and advanced economies.

Our sampling frame consisted of all Chinese high-tech manufacturing firms that were publicly listed between 2005 and 2011 and had a market capitalization above 50 million US dollars (based on 2012 financial reporting). Of the 426 firms identified, we conducted an executive survey on their FDI strategy. We asked the respondents to reflect on the latest FDI in order to mitigate memory biases. From June 2012 to March 2013 we received 131 completed responses, yielding a response rate of 31 percent. Of these, 75 responses were valid, as firms provided information on their latest FDI that occurred in the past three years (excluding those in Hong Kang, Macau and Taiwan). We examined potential non-response bias on a range of firm characteristics (including age, size and ownership), and found no 
significant concern. Combining the survey with secondary data, our final sample includes 75 Chinese high-tech firms venturing in 28 host countries (see Supplementary Material).

\section{Research design}

Given our holistic perspective and a focus on the complementarities of strategy tripod factors, we follow a set-theoretic approach, utilizing the technique of fuzzy-set qualitative comparative analysis (fsQCA). While traditional regression-based analysis is more suited for isolating the effect of individual factors, fsQCA models the concept of conjunctural causation (Schneider, Schulze-Bentrop, and Paunescu, 2010). Unlike cluster analysis and deviation scores, fsQCA allows for a detailed analysis of how causal conditions collectively contribute to the outcome in question (Crilly, 2011; Fiss, 2007, 2011). Moreover, fsQCA is suited for analysis based on a small-to-medium sized sample (Ragin, 2008).

\section{Measures and calibration}

Following prior fsQCA studies (Campbell, Sirmon, and Schijven, 2016; Crilly, 2011; Fiss, 2011; Schneider et al., 2010), we adopt the direct method, using both three-value and fourvalue schemes, to calibrate measures of outcomes and causal conditions. For the three-value scheme, external standards can be implemented by using specified values of an interval scale that correspond to the three key breakpoints of (a) fully in membership, (b) fully out membership, and (c) a crossover point (Fiss, 2011; Ragin, 2008). The four-value scheme marks "more in than out" as 0.67 and "more out than in" as 0.33 , in addition to fully in membership (set as 1) and fully out membership (set as 0 ). The four-value scheme is especially useful in situations where "researchers have a substantial amount of information 
about cases but the evidence is not systematic or strictly comparable from case to case" (Ragin, 2008: 31). Calibration anchors are reported in Table 1.

[Insert Table 1 about here]

Outcomes - high-distance and low-distance investments. We measured high-distance investment through the absolute value of institutional distance between home and host countries in the focal year, which employs the Institutions Pillar published by the World Economic Forum (WEF) in the Global Competitiveness Reports (Shaner and Maznevski, 2011). The index ranges from 1 to 7 , with higher values indicating better-developed institutions. We used the WEF index for three reasons. First, the index covers a number of dimensions of public and private institutions with weighted average. Differences in both public institutions of the wider regulatory environment and private institutions of corporate governance and ethics determine the level of unfamiliarity and discrimination hazards that a foreign firm faces. Second, the WEF index shows relatively stable scores, with reasonable across-period fluctuations for a given country, suggesting consistency of nation-level institutions. Lastly, although a range of measurements for institutional distance have been employed in previous studies, many arguably suffer from the conflation of institutional profile and institutional distance, particularly in the case of a single reference country (van Hoorn and Maseland, 2016). The WEF index varies for each country from one year to another, and China sits around the middle of the rankings, both of which factors mitigate empirical concerns over the profile-distance conflation. When calibrating high-distance investment, we followed the approach by Crilly (2011), and relied on external qualitative knowledge on judgment, and set 1.2 as the "fully in" anchor for high-distance membership 
(including Canada in 2012, the Netherlands in 2009, etc.), and 0.3 as the "fully out" point for high distance membership (including South Korea in 2012, Indonesia in 2012, etc.). Those scoring between 1.2 and 0.7 are considered to have a high degree of membership at the 0.67 level ("more in than out"; e.g., including Australia in 2011, Italy in 2010). Those between 0.7 and 0.3 receive 0.33 ("more out than in"; e.g., including Japan 2009, Philippine in 2012). As a unique analytical advantage, fuzzy set analysis allows us to analyze separately what relates to the negation of the outcome (Campbell et al., 2016). Thus, when calibrating low-distance investment, we treated it as negation of high-distance investment, and used an inverse of the measure described above (i.e., reverse "fully in" and "fully out" thresholds).

\section{Institution-based view - home and host political connections. For previously}

employed objective measures of political connections, biases may be introduced when objective connections are more tolerable and common in some countries than in others (Faccio, 2006). Following prior research on Chinese firms, we focus on managers' social and relational ties with government officials. Specifically, we measure home political connection using Peng and Luo's (2000) three items (with a 7-point Likert scale), where we asked executives to describe the extent to which they had utilized personal ties, networks and connections over the past three years with a) political leaders in the government, b) officials in industrial bureaus, and c) officials in regulatory and supporting organizations. For host political connection, we asked executives (using the same scale) about the extent to which they utilized political connections in the host country when undertaking their latest FDI (see Supplementary Material). The scale reliability is 0.83 for home political connections and 0.79 for host political connections. For these two factors, we coded membership as "fully in" for a 
response of 5 and above ("slightly extensive" "extensive" or "very extensive"), because all three options emphasize the meanings of "extensive", and "fully out" for a response of 3 or below ("slightly little", "little" or "very little"), because the three options focus on "little" (fewer) ties. As we took the mean of three items, those scoring between 5 and 4 are treated as 0.67 for "more in than out", while the "more out than in" $(0.33)$ range was between 4 and 3 . Resource-based view $-R \& D$ commitment and internationalization experience. Embracing Jansen, Van den Bosch and Volberda's (2006) broad view of firm innovation, we developed eight items to measure $R \& D$ commitment. We asked executives about evaluation on items such as "we invent new products and services" and "we experiment with new products and services in our local market" (see details in Supplementary Material). Through an exploratory factor analysis, we obtained one factor solution and termed it $R \& D$ commitment. We calibrated 4.75 or below as fully out membership of high R\&D commitment, and 5.75 and above as fully in membership of high R\&D commitment. The values between 5.75 and 5.25 are considered to have a high degree of membership at the 0.67 level. The values between 5.25 and 4.75 receive a low degree of membership at 0.33 . The comparatively higher scores were adjusted, because sampled high-tech firms generally placed higher value on $R \& D$ commitment, while listed firms had relatively sufficient financial resources to support their R\&D activities. For internationalization experience, we adopted Lu and Beamish's (2004) measure of the stock of internationalization experience prior to the latest FDI in year t-1. Specifically, we counted a firm's number of foreign subsidiaries and number of foreign countries in which it had invested from its annual reports, and divided these two counts by the maximum number of foreign subsidiaries and FDI host countries in our sample, 
respectively, to convert them from counts to ratios. We computed the average of these two ratios, so that our measure of internationalization experience ranges from 0 to 1 , with 1 representing the highest level of experience in our sample. Following Fiss (2011), we used distribution-adjusted anchor points of 0.10 (full membership), 0.05 (cross-over point), and 0 (full non-membership) to calibrate the level of internationalization experience.

Industry-based view - global environmental munificence and dynamism. Global environmental munificence (EM) and environmental dynamism (ED) were calculated based on data from the United Nations Industrial Development Organization (UNIDO) database. Following Fernhaber and Patel (2012), we regressed the natural logarithm of industry sales on time using a three-year moving window. For EM, we took the anti-log of beta as its measure, which represents the average industry growth rate. For ED, we took the anti-log of standard error of the beta. Higher standard errors indicate greater environmental discontinuities. In calibration, the adjusted data distribution approach was applied (Fiss, 2011). Industries with values below 0.82 are coded as entirely out of the set of munificent environment. The crossover value is set at 0.915 , while industries with values above 1.01 are coded as entirely in the set of munificent environment. Likewise, setting the crossover point at 1.0835 , we coded industries with ED value below 1.061 as fully out of high dynamism membership and those above 1.106 as fully in high dynamism membership.

\section{RESULTS}

We started the analysis by testing whether any factor qualifies for necessary conditions for high-distance investment, and its negation (low-distance investment), respectively. As shown in Table 2, none of the individual factors exceeds the consistency threshold of 0.90 in both 
tests (Greckhamer, 2011; Schneider et al., 2010). Therefore, we confirm that there is no individual factor as a necessary condition for both outcomes. In this study, our results are based on two sufficiency analyses, of which one is with the set of "high-distance investment" outcome, and the other with the negated set of this outcome, "low-distance investment".

[Insert Table 2 about here]

Our study adopts a frequency cutoff at 2.0, and a consistency threshold of 0.861 for high-distance investment solutions, and a frequency cutoff at 2.0, and consistency threshold of 0.859 , for low-distance investment solutions, in accordance with two analytical criteria. Firstly, we conducted a sufficiency analysis (see Supplementary Material) using Ragin's (2008) truth table algorithm to identify attribute combinations consistently linked to an outcome at the acceptable consistency benchmark of 0.80 . When analyzing high-distance investments, we followed Schneider et al. (2010), who choose a threshold that corresponds to a gap observed in the distribution of consistency scores; thus, our cut-off point falls in a clear gap between the fourth (0.859) and the fifth (0.819) raw consistency values. When analyzing low-distance investments, the gap approach is no longer clear. Thus, we adopted two complementary consistency measurements simultaneously. One is using the Proportional Reduction in Inconsistency (PRI) value - a measure of fit to compute the degree to which a solution is sufficient for the outcome rather than the negation of the outcome (Ragin, 2008). Given that the truth table shows 57 out of 62 solutions (about 92\%) with raw consistency values greater than the threshold of 0.80 , we adopted a more stringent PRI cut-off score of 0.70 to rule out simultaneous subset relations of attribute combinations in both the outcome and its absence. Further, following Schneider and Wagemann (2012), who propose that the 
"PRODUCT" value of consistency - a result of multiplying the consistency measure and PRI - should be used as a complementary consistency measurement. We adopted a higher cut-off (0.60) of PRODUCT, which also justifies our selected raw consistency cut-off point as 0.861 . Table 3 presents the results of our analyses. The configurational solutions are presented in the style of Ragin and Fiss (2008), where black circles (Ï ) indicate the presence of a condition (or factor), and circled crosses $(\otimes)$ indicate its absence. Large circles indicate core conditions, while small ones are peripheral conditions. Blank spaces indicate ambiguous situations, in which the corresponding condition may be either present or absent, and therefore they play no significant role in the solution. Based on core conditions (Fiss, 2011; Meuer, 2014), Table 3 shows that our analysis results in three major solutions, which further indicate the presence of both core and peripheral conditions. We obtain a coverage of 0.41 on high-distance investment solutions and 0.57 on low-distance investment solutions. Our coverage indicates the empirical importance of the solution as a whole (Crilly, 2011; Ragin, 2008). When measuring how well a solution corresponds with data, previous studies suggest an acceptable consistency (e 0.80) (Campbell et al., 2016; Fiss, 2011). In this study, our individual and overall solutions exhibit acceptable consistency levels. In Table 3, the presence of several solutions points to a situation of first-order, or across-type, equifinality of solutions (Fiss, 2011). The neutral permutations within solutions 1 (1a and 1b) and solution 4 ( $4 \mathrm{a}$ and $4 \mathrm{~b}$ ) further illustrate the existence of second-order, or within-type, equifinality. Various sensitivity checks, including using higher consistency cut-off, higher frequency cutoff, different calibration rules, and reduced threshold, support our configurations (details are available upon request). 
[Insert Table 3 about here]

Each of four configurations on the left side of Table 3 represents a unique combination of internal and external factors that help EMNEs overcome high institutional distance in foreign expansion. We also conducted negation analysis, so that the right side of Table 3 reports four configurations representing EMNEs' overcoming low institutional distance. Solutions $1 \mathrm{a}$ and $1 \mathrm{~b}$ are identical in core conditions, i.e., the presence of home political connections and global environmental munificence, as well as the absence of R\&D commitment. Yet they differ in peripheral conditions. In Solution 1a, the absence of host political connections and internationalization experience and presence of global environmental dynamism play contributing roles. Solution $1 \mathrm{~b}$ features host political connections and internationalization experience, and the lack of environmental dynamism, as contributing conditions. Solution 2 describes the configuration where host political connections and internationalization experience and the absence of R\&D commitment play central roles, whilst home political connections and environmental dynamism, as well as the absence of environmental munificence, play contributing roles. Solution 3 requires R\&D commitment, global environmental dynamism, and the absence of internationalization experience as core conditions, while the absence of environmental dynamism and presence of home and host political connections contribute as peripheral conditions.

For low-distance investment solutions, Solutions $4 \mathrm{a}$ and $4 \mathrm{~b}$ are identical in core conditions (i.e., the presence of host political connections and R\&D commitment), but they differ at the peripheral level in two industry-based factors (global EM and ED). Solution 4a represents a configuration that has home political connections, global ED and absence of 
global EM, as contributing conditions. Solution $4 \mathrm{~b}$, as a 'sister' permutation, shows one difference of presenting global EM but without ED. Solution 5 includes R\&D commitment and global environmental dynamism as central factors. The presence of home political connections and internationalization experience and absence of global environmental munificence are peripheral contributing factors. Unlike other low-distance investment solutions, Solution 6 requires the presence of global environmental munificence and dynamism, but makes absence of institutional and resource factors contributing roles. Below, we discuss these configurations in detail by reference to the theories of political connections.

\section{DISCUSSION}

\section{Home political connections}

Among firms that have overcome high institutional distance in foreign expansion, we identify a distinct group of firms relying heavily on home political connections (Solutions 1a and 1b). Given the institutional and informational benefits, one might posit that networking with home officials should be universally helpful in addressing differences in formal institutions. However, our findings suggest otherwise. The importance of home political connections in helping firms to overcome high institutional distance depends on the gestalts of other factors. The core conditions suggest that firms relying on home ties are only found in munificent industries, and they share a lack of commitment to R\&D. This is the case where some Chinese firms want to capture the emerging opportunities that a fast-growing industry affords yet find themselves incompetent in $\mathrm{R} \& \mathrm{D}$ and innovation when compared to mature multinationals and local incumbents. This may be because these firms have specialized in low-cost production and now seek to move up the value chain to sustain growth when 
abundant resources in the industrial environment allow (Castrogiovanni, 1991). However, institutional distance and the resulting liabilities of foreignness significantly raise the entry barrier, making it challenging for firms without strong R\&D capacity to tap into resources in distant countries. Home political connections become particularly crucial in this context. It is well-documented that the Chinese government promotes industrial development by supporting domestic firms' internationalization, and this support compensates for the firms' competitive disadvantages in the global market (Luo et al., 2010).

Fuzzy-set analysis allows us not only to identify configurational solutions, but also to pinpoint the representative cases in our sample for each solution. Representing Solution 1a, Xixia Pump specializes in water pump manufacturing for both petrol and electric automobiles. Because of the fast growth in Chinese automobile industry after 2010, Xixia has occupied a substantial market share through its matured water pump products. Driven by the industrial trend and its limited R\&D capability in water pumps of electric vehicle, Xixia, the only listed automobile part company in its province, requested favorable FDI policy from the local government, and successfully set up its first US subsidiary for product upgrading in 2012. BYD Co., Ltd., as a representative firm for Solution 1b, has been competing in the highgrowth electric automobile sector since 2008. While BYD's patents accumulation is largely confined to vehicle manufacturing, the company has ambitions to conquer the global electric bus market. With abundant political connections in Shenzhen, where it is headquartered, BYD lobbied the local government to support its electric bus internationalization with favorable policies, and it was also selected as the exclusive electric bus/taxi provider in this city. In 2012, BYD Canada was established to hire local engineers for the testing of electric 
buses, which served as the springboard to enter developed markets and enhance its R\&D capability. Both representative firms' high-distance investments appear to be motivated by strategic asset-seeking purposes (Cui et al., 2017), in line with our theorization about how home political connections may help internationalizing firms.

In addition to the core characteristics, we found two sets of peripheral complementary conditions. One might note in passing that internationalization experience and the use of host political connections are interrelated in this case: firms without internationalization experience may be incompetent in developing ties with political agents in a distant country and deploying the agents in their own favor. Based on core conditions, we propose that:

Proposition 1: Home political connections are most useful in helping EMNEs to overcome high institutional distance in FDI when the firms operate in a munificent industry and lack commitment to $R \& D$.

\section{Host political connections}

Our analysis reveals another group of Chinese firms that have overcome high institutional distance through FDI (Solution 2). Although they also show little commitment to R\&D and innovation activities, a defining characteristic of this group is their extensive use of host political connections, combined with strong internationalization experience. One could argue that their foreign venturing in distant countries is not founded upon superior technological resources, but upon political capabilities of engaging with host government agents.

It is unsurprising that the use of host political connections is closely complemented by internationalization experience. In institutionally distant countries, foreign EMNEs' political and social legitimacy is often questioned to an extent that threatens the firms' survival in that 
market. Yet developing and utilizing political networks as a means to tackle this challenge carry substantial costs and risks (Siegel, 2007). In general, political connections come with the expectation of reciprocity. MNEs may support the political agents' agenda by providing a range of benefits, including employment, exports, political contributions and personal considerations, in exchange for regulatory favors (Boddewyn and Brewer, 1994). However, in an institutionally distant country, it is difficult for inexperienced firms to identify the right form of reciprocity. Firms that have accumulated extensive operational experience in foreign markets learn to adapt to the changing institutional environment, and develop institutional capabilities regarding international venturing (Zhou and Guillén, 2015). Research confirms that institutional knowledge and capabilities of penetrating host country state-business networks are transferable across borders (Frynas, Mellahi, and Pigman, 2006). Additionally, our analysis reveals the peripheral, contributing roles of home political connections and industrial environment. A dynamic yet resource-meager environment renders static resource endowments less important and requires responsiveness and flexibility (Lawrence and Lorsch, 1967). For firms without innovation capacities to compete in such an environment, seeking forward-looking information through political channels becomes a viable strategy.

The representative firm for Solution 2, Cooltech Power, is a power-generator manufacturer founded in 2002. Being a low-cost producer, Cooltech exports its products to most continents. Armed with internationalization experience, Cooltech came to an agreement with the government of Singapore in 2007, and started to develop a good relationship with host government agents. Since then the company has become a reliable power-generator supplier for the Singaporean government. Based on mutual trust between the company and 
host government agents, Cooltech then established its first and the only foreign subsidiary in Singapore in 2011. The Singaporean subsidiary works as Cooltech's sub-headquarters for international business, while creating much-desired new employment in the host country. Motivated by market-seeking purposes, Cooltech finally gained favourable treatment from the Singaporean government and managed to overcome high institutional distance in foreign venturing. Based on core conditions, then, we propose that:

Proposition 2a: Host political connections are most useful in helping EMNEs to overcome high institutional distance in FDI when the firms lack commitment to R\&D but have accumulated extensive internationalization experience.

Consistent with the assumption of asymmetric causality, our negation analysis reveals distinct configurations of the strategy tripod factors associated with Chinese technology firms investing in low-distance countries. We identify a group of firms that simultaneously utilize host political connections and commit to R\&D activities (Solutions 4a and 4b). Independently, each of the market and non-market strategies should be of use in this context. Low institutional distance reduces the uncertainty that foreign firms face when engaging with local political agents (Mudambi and Navarra, 2002). Familiarity with the structure of policy making and economic institutions allows the firm to identify the right agent who would appreciate the reciprocal benefits the firm brings to the table, and also feed it with useful insider information upon which competitive advantages can be based (Boddewyn and Brewer, 1994). On the other hand, the institutional compatibility between home and host locations determines the firm's capacity to gain insider status in the local business network (Cantwell, 2009). When firms are deeply embedded in dense networks of production, information flow 
through the supply chain improves focal firms' knowledge acquisition, making product innovation and process adaptation more efficient (Johanson and Vahlne, 2009). R\&Dintensive firms are more attracted to locations where investment in innovation tends to be more efficient and generates a higher return.

However, our configurational approach suggests that market and non-market strategies are mutually reinforcing in this context. Government officials are more receptive to R\&D-intensive MNEs originating from an institutionally proximate country because of familiarity and compatibility. $R \& D$ firms also tend to attach more importance to the endorsement of host political agents, since this enhances their legitimacy and credibility as viewed by the local business network. The more embedded in the business network, the more efficient their R\&D activities will be. It could be inferred from this pattern that low-distance investment may not incur negligible costs and liabilities. Instead, it poses some threshold requirements for foreign investment, and some firms are better positioned to overcome these thresholds and seize opportunities in institutionally proximate countries. The representative firm for Solution 4a, Silan Electronics, specializes in integrated circuit manufacturing. While the integrated circuit industry requires continuous R\&D investment, its global growth potential is limited because of industrial maturity. To increase market share overseas, Silan has to rely heavily on political connections in targeted host countries. In the last decade, there were several diplomatic incidents between South Korea and Japan that forced Korean MNEs to change electronic part suppliers from Japan to other countries. After receiving this “message" from proximate politician(s), in 2009, Silan established its first Asian subsidiary in South Korea with support from the Korean government. Acquired legitimacy helped the 
firm gradually increase its sales, and it became the largest foreign integrated circuit supplier in this country. Sany Heavy Machinery Co., Ltd., the representative firm for Solution 4b, is one of the largest construction machinery manufacturers in the world. To capture the growth trend in South America, Sany accepted an invitation from the Brazilian government, and built a factory with a R\&D center there in 2012. A good relationship with Brazilian politicians conferred on Sany strong legitimacy, and helped the firm exploit ownership advantages in a foreign country. Motivated primarily by market-seeking purposes, both representative firms for Solutions $4 \mathrm{a}$ and $4 \mathrm{~b}$ ventured into low-distance countries through enhanced legitimacy in host countries. Based on core conditions, we propose:

Proposition 2b: Host political connections are most useful in helping EMNEs to venture in low institutional distance countries when the firms are strongly committed to $R \& D$.

\section{Transfer of political connections across institutional contexts}

Solutions 3 and 5 identify two distinct groups of firms investing in high-distance and lowdistance countries, respectively. Despite the opposing foreign contexts in which they venture, these two groups share some important characteristics. Both operate in highly dynamic industries, and both commit heavily to R\&D. Dynamic marketplaces confer ample opportunities on EMNEs to acquire new technological, marketing and managerial expertise, and to compete with incumbent firms by providing novel product and process solutions, in both high and low distance countries. It is well-documented that, in a dynamic environment, rapid and unpredictable changes in market demand, consumer taste and competitive tactics undermine the effectiveness of established resources and routines (Lawrence and Lorsch, 1967). To ensure survival, firms need to maintain competitive flexibility in and 
responsiveness to the market (Miller and Friesen, 1983). Investing in innovation then becomes a relevant strategy. One could argue that Solutions 3 and 5 point to the cases where institutional distance poses fewer constraints for EMNEs, and foreign venturing depends on the firms' capacity to respond to dynamic market changes. To a lesser extent, these firms are all well-connected with home political agents and deploy political aids for their own benefit. However, comparing Solution 3 with Solution 5 reveals an interesting change in the efficacy of host political connections. In low-distance countries, resource-based advantages are less likely to be impaired by unfamiliarity and discriminating hazards. Latecomer innovators compete in the market solely on product innovation and process adaptation, and they seldom resort to ties with local political agents. Since developing and maintaining host political connections require reciprocal favors and incur significant costs, these becomes dispensable to firms that focus on market capabilities. In contrast, in high-distance countries, host political connection is regarded as important, and it is employed by innovation-oriented EMNEs. It is conceivable that, while these firms tend to base competitive advantages on innovative products and processes in this particular environment, locally embedded ties with political agents afford some positive utility in a far-removed institution where foreign firms suffer from information asymmetry and discriminatory treatment at the hands of various stakeholders. This is especially the case when R\&D-intensive firms seek to source new knowledge from a foreign knowledge cluster. Very often such activities are perceived negatively by stakeholders; motivations are questioned and potential benefits ignored. The intended reverse knowledge transfer to the headquarters could be interpreted as a case of technology leakage (Meyer et al., 2014). Political legitimacy becomes crucial under these 
circumstances, and the lack of that attracts additional regulatory pressures. Engaging with selected local political agents lifts regulatory burdens and enhances the firms' trustworthiness in the eyes of many other stakeholders, making it a viable strategy in theory.

Our findings suggest that, in reality, these benefits outweigh the costs of developing political connections in the absence of internationalization experience. As a representative firm for Solution 5, Changhong Co. Ltd. is a leading home appliance manufacturer in China, with multi-country operations overseas. Changhong entered the United Arab Emirates market in 2010, and successfully met local customers' needs with its quality home appliances, as a result of continuous investment in R\&D. In contrast, Yiling Pharmaceutical (Solution 3) had to rely on political connections in the UK to overcome high institutional distance in 2011 . In response to reverse knowledge transfer concerns from the British government, Yiling accepted suggestions from local governmental agents, and built a medical research center with Cardiff University. Thus, R\&D outputs in the UK subsidiary are shared with the local community, while Yiling also created new jobs to further satisfy the host government. Networking with political agents helped Yiling obtain informational advantages and enhance its legitimacy in a far-removed institutional environment. While host political connection is in the configuration (Solution 5) sufficient for latecomer innovators to overcome high institutional distance in FDI, its promotional role disappears when similar firms venture into low-distance countries. The importance of host political connection seems replaced by some degree of internationalization experience. Hence: 
Proposition 3: For R\&D-intensive firms operating in a highly dynamic industry, host political connections represent an important asset in high institutional distance countries and become dispensable in low institutional distance countries.

\section{Theoretical contributions}

Why and how MNEs can overcome "costs of doing business abroad" or "liability of foreignness" has been an intriguing question for IB scholars (Eden and Miller, 2004; Zaheer, 1995). Through the lens of the strategy tripod perspective, we extend previous studies by explicating the efficacy of political connections in overcoming institutional distance under varying complementary conditions, and offer insights into several lines of IB literature.

First, we extend the non-market strategy literature regarding political connections. Previous research has primarily theorized political connection as a substitute for marketsupporting institutional infrastructures in emerging countries (Li et al., 2008; Luo, 2003). Less discussed are the complementary conditions for political connections required to overcome institutional barriers to EMNEs' internationalization. To fill this gap, we argue that home and host connections provide distinct mechanisms through which firms can mitigate liabilities of foreignness arising from institutional distance, and that the cost and benefit of political networking are not constant for all firms. Our configurational analyses suggest that, while political networking is useful for EMNEs' internationalization, its importance crucially depends on constellations of complementary conditions. For instance, R\&D-intensive firms are best placed to extract benefits from political networking with host officials when venturing into low-distance countries (Solutions $4 \mathrm{a}$ and $4 \mathrm{~b}$ ). This is because developing and maintaining political ties at home and abroad entail significant cost, commitment and risk. 
Only when the anticipated benefits outweigh the costs would managers choose to employ such a non-market strategy. This tradeoff is both firm- and industry-specific. Moreover, the extant contingency perspective in the non-market strategy literature focuses on the presence of certain factors that condition the value of political ties (Sun et al., 2012). Our analysis also suggests that, for a given type of connection to attain great importance, certain factors must be non-existent. For instance, in an institutionally distant country, non-R\&D firms may find themselves in a better position to establish links with host political agents through which the firms can enhance political legitimacy and exploit information asymmetry at the expense of competitors (Solution 2). This is because R\&D-intensive foreign technology firms are more likely to be perceived negatively, and associated more with threats than opportunities, including technology leakage and loss of competitiveness of the domestic industry (Globerman and Shapiro, 2009). We clearly show that, in any given institutional context, the perceived usefulness of political ties is not uniform, but a distinct function of the presence and absence of complementary resource and industry conditions.

Our comparative analysis of firms venturing in high-distance and low-distance countries yields two important insights. First, we show that, given similar complementary conditions, the efficacy of connection could change across institutional settings (Solutions 3 and 5). This affirms the conjectures by previous studies (Dieleman and Boddewyn, 2012; Li et al., 2009; Meyer et al., 2014). However, we bring much-needed nuance to this conclusion. Only for R\&D-intensive firms operating in a highly dynamic industry would host political networking switch from an important non-market strategy to a dispensable one as institutional difference decreases. Second, the mechanisms through which host political 
connections benefit EMNEs differ, depending on the institutional distance between the home and host country, so that, for the same type of connections to be useful, different complementary conditions are required (Solutions 2 and 4). In high-distance countries, legitimacy deficiency is a salient issue. EMNEs suffer from inherent liabilities of foreignness and discrimination hazards in a host environment where formal institutional infrastructures depart vastly from those of the home country (Eden and Miller, 2004). Under these circumstances, internationalization experience becomes an important complementary condition for firms to grasp the nuance of political networking. For instance, some political behavior considered normal in the home country, such as internalizing the political agents into the firm's hierarchy or making political contributions, may be legally restricted and may undermine legitimacy in a different country (Boddewyn and Brewer, 1994). The expected costs and uncertainty in relation to political networking would deter the use of such nonmarket strategies by inexperienced EMNEs to overcome institutional distance. In lowdistance countries, legitimacy becomes less a concern, and benefits of host political networking accrue mainly from informational advantages. Formal regulations and the rules with which competition is organized are similar between two proximate institutions, making it easier for firms to embed themselves in the local production network. Nevertheless, the policy environment poses potential threats to the existing market structure on which exchange relationships are based (Choi et al., 2015). As a means to tackle external uncertainty, host political connections provide crucial information on how to deal with upcoming regulatory changes and even take advantage of potential political interference. In this case, the efficacy 
of host political networking is the highest for R\&D-intensive firms whose innovation efficiency crucially depends on relations with the local supply chain partners.

Second, we contribute to the literature on institutional distance in IB. Much of the extant research views home-host institutional distance as an explanans of various strategies, including investment location, entry mode and ownership level. While IB researchers agree that home-host institutional distance poses significant challenges to MNEs, it remains unclear why some EMNEs - given their inadequate resources and capabilities in general - are not constrained by institutional distance. Through identifying configurations of causal conditions pertaining to firms embracing great institutional differences, we extend the knowledge about EMNEs' capacity to overcome institutional distance in international expansion. Moreover, previous studies assume that low institutional distance investments involve negligible costs due to the linear effect of distance embedded in regression-based methods. One implication is that the factors causing high-distance and low-distance investments are symmetric: lowdistance investments are caused by what fails to overcome significant institutional distance. Our empirical results relax this assumption by identifying four distinct configurations associated with EMNEs' low-distance FDI that are not the opposite of what guarantees highdistance investments. It is differences in kind rather than those in level that explain variances in foreign entry. Our findings also corroborate the existence of threshold requirements for MNEs' expansion into institutionally proximate environments. Managers ignoring this threshold often fall into the overconfidence trap (O'Grady and Lane, 1996).

However, it is worth noting that the results do not completely nullify the linearity assumption. Solutions 1a and 6 represent a comparable pair of configurations across two 
opposing institutional contexts. Both are resource-meager, and operate in dynamic and munificent industries. A striking difference is that home political connection is an important asset in institutionally distant countries, but it turns into a liability in proximate ones. Significant costs and liabilities of foreignness are expected for resource-meager and inexperienced Chinese firms to operate in a far-removed institutional environment. Institutional support from home political agents becomes an important substitute for firmspecific intangibles (Cui and Jiang, 2012). Financial aid and administrative assistance are commonly offered by the Chinese government to promote internationalization and industrial catch-up (Luo et al., 2010). These, to a large extent, offset the extra costs arising from distance-induced uncertainty, unfamiliarity and discrimination that firms have to bear. In contrast, our sampled Chinese technology firms venturing in institutionally proximate countries do not possess home political connections. While it seems that low institutional distance poses negligible cost to foreign firms, as many have assumed, we stress that the configuration of industry-based conditions has to be met before claiming this conclusion.

Third, we contribute to the strategy tripod literature by testing its three legs (resource, industry, and institution) simultaneously and generating equifinal configurations for EMNEs' international expansion strategy. It has been well argued that studying the global strategies of MNEs and particularly EMNEs needs to combine wisdoms from three theoretical traditions: the industry-based, resource-based and institution-based views (Peng et al., 2009; Peng, Wang, and Jiang, 2008). Yet very few studies have integrated these theoretical strands in empirical testing. Our set-theoretic approach facilitates the empirical investigation of complex interdependencies, and illustrates that EMNEs' capacity to embrace institutional 
differences is contingent on the overall configurations of institutional, resource and industry factors. As the first paper testing three-leg interactions simultaneously, our study attests to the theoretical efficacy of the strategy tripod perspective and extends the application of this framework in IB.

\section{Limitations and future research}

Limitations of this study lead to several future research directions. First, following the convention (Eden and Miller, 2004; Zhou and Guillen, 2016), we focus mainly on the cost implications and liability of foreignness in conceptualizing institutional distance. Rooted in the new institutional economics, this view has a closer bearing on political connections, as well as our research questions. That said, recent Varieties of Capitalism (VoC) studies argue that institutional difference may incur benefits through the exploitation of comparative advantages (e.g., Jackson and Deeg, 2008; Witt and Jackson, 2016). We call for future research to incorporate both cost and benefit dimensions of institutional difference to yield new insights into specific constraints on EMNEs' cross-border transfer of practices.

Second, while we do not explicitly claim that political networking is valuable in the sense that it would contribute to the success of foreign venturing, recent studies have examined the performance implications of foreign political connections (Sojli and Tham, 2017) and particularly for cross-border mergers and acquisitions (Brockman et al., 2013). We encourage future research to conjoin our work with this line of inquiry to investigate varying complementary conditions that would enhance the value-creating effect of political networking in response to different institutional settings. 
Finally, we note that the tripod configurations may change over time, especially given the on-going institutional transition in emerging economies that influence not only resource availability for strategic initiatives but also resource utilization and industrial conditions. Future research may incorporate the time dimension into the theoretical framework and empirical design to examine the dynamic three-leg interactions for EMNEs' global strategies.

\section{ACKNOWLEDGEMENT}

We greatly appreciate the feedback and guidance from the Special Issue Editors and two anonymous reviewers. We are grateful to Professor Mike Peng for valuable comments on an earlier draft of this article. The third author appreciates financial support of Victoria University (RDGS 22-12) and Curtin University (CBS Journal Publication Support Round 1 2016).

\section{REFERENCES}

Barney J. 1991. Firm resources and sustained competitive advantage. Journal of Management 17: 99-120.

Berry H, Guillen MF, Zhou N. 2010. An institutional approach to cross-national distance. Journal of International Business Studies 41: 1460-1480.

Boddewyn JJ. 1988. Political aspects of MNE theory. Journal of International Business Studies 19: 341-363.

Boddewyn JJ, Brewer TL. 1994. International-business political behavior: New theoretical directions. Academy of Management Review 19: 119-143.

Boter H, Holmquist C. 1996. Industry characteristics and internationalization processes in small firms. Journal of Business Venturing 11: 471-487.

Brockman P, Rui OM, Zou H. 2013. Institutions and the performance of politically connected M\&As. Journal of International Business Studies 44: 833-852.

Buckley PJ, Clegg LJ, Cross AR, Liu X, Voss H, Zheng P. 2007. The determinants of Chinese outward foreign direct investment. Journal of International Business Studies 38: 499-518.

Campbell JT, Sirmon DG, Schijven M. 2016. Fuzzy logic and the market: A configurational approach to investor perceptions of acquisition announcements. Academy of Management Journal 59: 163-187.

Cantwell J. 2009. Location and the multinational enterprise. Journal of International Business Studies 40: 35-41. 
Castrogiovanni GJ. 1991. Environmental munificence: A theoretical assessment. Academy of Management Review 16: 542-565.

Choi S-J, Jia N, Lu J. 2015. The structure of political institutions and effectiveness of corporate political lobbying. Organization Science 26: 158-179.

Crilly D. 2011. Predicting stakeholder orientation in the multinational enterprise: A midrange theory. Journal of International Business Studies 42: 694-717.

Cuervo-Cazurra A, Genc ME. 2011. Obligating, pressuring, and supporting dimensions of the environment and the non-market advantages of developing-country multinational companies. Journal of Management Studies 48: 441-455.

Cui L, Fan D, Liu X, Li Y. 2017. Where to seek strategic assets for competitive catch-up? A configurational study of emerging multinational enterprises expanding into foreign strategic factor markets. Organization Studies in press.

Cui L, Jiang F. 2012. State ownership effect on firms' FDI ownership decisions under institutional pressure: A study of Chinese outward-investing firms. Journal of International Business Studies 43: 264-284.

Cui L, Li Y, Li Z. 2013. Experiential drivers of foreign direct investment by late-comer Asian firms: The Chinese evidence. Journal of Business Research 66: 2451-2459.

Dess GG, Beard DW. 1984. Dimensions of organizational task environments. Administrative Science Quarterly 29: 52-73.

Dieleman M, Boddewyn JJ. 2012. Using organization structure to buffer political ties in emerging markets: A case study. Organization Studies 33: 71-95.

Du X, Luo J-h. 2016. Political connections, home formal institutions, and internationalization: Evidence from China. Management and Organization Review 12: 103-133.

Duanmu J-L. 2014. State-owned MNCs and host country expropriation risk: The role of home state soft power and economic gunboat diplomacy. Journal of International Business Studies 45: 1044-1060.

Eden L, Miller SR. 2004. Distance matters: Liability of foreignness, institutional distance and ownership strategy. In Theories of the Multinational Enterprise: Diversity, Complexity and Relevance (Advances in International Management, Volume 16) Hitt MA, Cheng JLC (eds.), Emerald: Bingley, UK.

Erramilli MK. 1991. The experience factor in foreign market entry behavior of service firms. Journal of International Business Studies 22: 479-501.

Faccio M. 2006. Politically connected firms. American Economic Review 96: 369-386.

Fernhaber SA, Patel PC. 2012. How do young firms manage product portfolio complexity? The role of absorptive capacity and ambidexterity. Strategic Management Journal 33: 1516-1539.

Fiss PC. 2007. A set-theoretic approach to organizational configurations. Academy of Management Review 32: 1180-1198.

Fiss PC. 2011. Building better causal theories: A fuzzy set approach to typologies in organization research. Academy of Management Journal 54: 393-420.

Frynas JG, Mellahi K, Pigman GA. 2006. First mover advantages in international business and firm-specific political resources. Strategic Management Journal 27: 321-345.

Gaur AS, Lu JW. 2007. Ownership strategies and survival of foreign subsidiaries: Impacts of institutional distance and experience. Journal of Management 33: 84-110. 
Globerman S, Shapiro D. 2009. Economic and strategic considerations surrounding Chinese FDI in the United States. Asia Pacific Journal of Management 26: 163-183.

Greckhamer T. 2011. Cross-cultural differences in compensation level and inequality across occupations: A set-theoretic analysis. Organization Studies 32: 85-115.

Guillén MF, Garcia-Canal E. 2009. The American model of the multinational firm and the "new" multinationals from emerging economies. Academy of Management Perspectives 23: 23-35.

Haveman HA, Jia N, Shi J, Wang Y. 2017. The dynamics of political embeddedness in China. Administrative Science Quarterly 62: 67-104.

Hymer SH. 1976. The International Operations of National Firms: A Study of Foreign Direct Investment. MIT Press: Cambridge, MA.

Jackson G, Deeg R. 2008. Comparing capitalisms: Understanding institutional diversity and its implications for international business. Journal of International Business Studies 39: $540-561$.

Jansen JJP, Van Den Bosch FAJ, Volberda HW. 2006. Exploratory innovation, exploitative innovation, and performance: effects of organizational antecedents and environmental moderators. Management Science 52: 1661-1674.

Johanson J, Vahlne J-E. 1977. The internationalization process of the firm: A model of knowledge development and increasing foreign market commitments. Journal of International Business Studies 8: 23-32.

Johanson J, Vahlne J-E. 2009. The Uppsala internationalization process model revisited: From liability of foreignness to liability of outsidership. Journal of International Business Studies 40: 1411-1431.

Lawrence P, Lorsch J. 1967. Organization and Environment. Harvard University Press: Cambridge, MA.

Li HY, Atuahene-Gima K. 2002. The adoption of agency business activity, product innovation, and performance in Chinese technology ventures. Strategic Management Journal 23: 469-490.

Li HY, Zhang Y. 2007. The role of managers' political networking and functional experience in new venture performance: Evidence from China's transition economy. Strategic Management Journal 28: 791-804.

Li JJ, Poppo L, Zhou KZ. 2008. Do managerial ties in China always produce value? Competition, uncertainty, and domestic vs. foreign firms. Strategic Management Journal 29: 383-400.

Li JJ, Zhou KZ, Shao AT. 2009. Competitive position, managerial ties, and profitability of foreign firms in China: An interactive perspective. Journal of International Business Studies 40: 339-352.

Lu J, Liu X, Wang H. 2011. Motives for outward FDI of Chinese private firms: Firm resources, industry dynamics, and government policies. Management and Organization Review 7: 223-248.

Lu J, Liu X, Wright M, Filatotchev I. 2014. International experience and FDI location choices of Chinese firms: The moderating effects of home country government support and host country institutions. Journal of International Business Studies 45 : 428-449. 
Lu JW, Beamish PW. 2004. International diversification and firm performance: The S-curve hypothesis. Academy of Management Journal 47: 598-609.

Lumpkin GT, Dess GG. 1995. Simplicity as a strategy-making process: The rffects of stage of organizational development and environment on performance. Academy of Management Journal 38: 1386-1407.

Luo Y. 2001. Toward a cooperative view of MNC-host government relations: Building blocks and performance implications. Journal of International Business Studies 32: 401-419.

Luo Y. 2003. Industrial dynamics and managerial networking in an emerging market: The case of China. Strategic Management Journal 24: 1315-1327.

Luo Y, Xue Q, Han B. 2010. How emerging market governments promote outward FDI: Experience from China. Journal of World Business 45: 68-79.

Mellahi K, Frynas JG, Sun P, Siegel D. 2016. A review of the nonmarket strategy literature: Toward a multi-theoretical integration. Journal of Management 42: 143-173.

Meuer J. 2014. Archetypes of inter-firm relations in the implementation of management innovation: A set-theoretic study in China's biopharmaceutical industry. Organization Studies 35: 121-145.

Meyer KE, Ding Y, Li J, Zhang H. 2014. Overcoming distrust: How state-owned enterprises adapt their foreign entries to institutional pressures abroad. Journal of International Business Studies 45: 1005-1028.

Meyer KE, Estrin S, Bhaumik SK, Peng MW. 2009. Institutions, resources, and entry strategies in emerging economies. Strategic Management Journal 30: 61-80.

Miller D, Friesen PH. 1983. Strategy-making and environment: The third link. Strategic Management Journal 4: 221-235.

Mudambi R, Navarra P. 2002. Institutions and internation business: A theoretical overview. International Business Review 11: 635-646.

Nielsen BB, Nielsen S. 2010. Understanding the internationalization-performance relationship: A multilevel approach. In Advances in International Management. Devinney T, Pedersen T, Tihanyi L (eds.), Emerald: New York.

North D. 1990. Institutions, Institutional Change and Economic Performance. Cambridge University Press: Cambridge, UK.

O'Grady S, Lane HW. 1996. The psychic distance paradox. Journal of International Business Studies 27: 309-333.

Park SH, Luo YD. 2001. Guanxi and organizational dynamics: Organizational networking in Chinese firms. Strategic Management Journal 22: 455-477.

Peng MW. 2004. Identifying the big question in international business research. Journal of International Business Studies 35: 99-108.

Peng MW. 2012. The global strategy of emerging multinationals from China. Global Strategy Journal 2: 97-107.

Peng MW, Luo Y. 2000. Managerial ties and firm performance in a transition economy: The nature of a micro-macro link. Academy of Management Journal 43: 486-501.

Peng MW, Sun SL, Pinkham B, Chen H. 2009. The institution-based view as a third leg for a strategy tripod. Academy of Management Perspectives 23: 63-81. 
Peng MW, Wang DYL, Jiang Y. 2008. An institution-based view of international business strategy: A focus on emerging economies. Journal of International Business Studies 39: $920-936$.

Porter ME. 1980. Competitive Strategy. Free Press: New York, NY.

Ragin CC. 2008. Redesigning Social Inquiry: Fuzzy Sets and Beyond. University of Chicago Press: Chicago, IL.

Ragin CC, Fiss PC. 2008. Net effects analysis versus configurational analysis: An empirical demonstration. In Redesigning Social Inquiry: Fuzzy Sets and Beyond. Ragin CC (ed.), University of Chicago Press: Chicago, IL.

Schneider C, Wagemann C. 2012. Set-theoretic Methods for the Social Sciences. Cambridge University Press: Cambridge, UK.

Schneider MR, Schulze-Bentrop C, Paunescu M. 2010. Mapping the institutional capital of high-tech firms: A fuzzy-set analysis of capitalist variety and export performance. Journal of International Business Studies 41: 246-266.

Shaner J, Maznevski M. 2011. The relationship between networks, institutional development, and performance in foreign investments. Strategic Management Journal 32: 556-568.

Shenkar O. 2001. Cultural distance revisited: Towards a more rigorous conceptualization and measurement of cultural differences. Journal of International Business Studies 32: 519-535.

Shi W, Markóczy L, Stan CV. 2014. The continuing importance of political ties in China. Academy of Management Perspectives 28: 57-75.

Siegel J. 2007. Contingent political capital and international alliances: Evidence from South Korea. Administrative Science Quarterly 52: 621-666.

Sojli E, Tham WW. 2017. Foreign political connections. Journal of International Business Studies 48: 244-266.

Sun P, Mellahi K, Thun E. 2010. The dynamic value of MNE political embeddedness: The case of the Chinese automobile industry. Journal of International Business Studies 41: 1161-1182.

Sun P, Mellahi K, Wright M. 2012. The contingent value of corporate political ties. Academy of Management Perspectives 26: 68-82.

Sun P, Mellahi K, Wright M, Xu H. 2015. Political tie heterogeneity and the impact of adverse shocks on firm value. Journal of Management Studies 52: 1036-1063.

van Hoorn A, Maseland R. 2016. How institutions matter for international business: Institutional distance effects vs institutional profile effects. Journal of International Business Studies 47: 374-381.

Wang C, Hong J, Kafouros M, Boateng A. 2012. What drives outward FDI of Chinese firms? Testing the explanatory power of three theoretical frameworks. International Business Review 21: 425-438.

Witt MA, Jackson G. 2016. Varieties of Capitalism and institutional comparative advantage: A test and reinterpretation. Journal of International Business Studies 47: 778-806.

$\mathrm{Wu}$ J, Li S, Li Z. 2012. The contingent value of CEO political connections: A study on IPO performance in China. Asia Pacific Journal of Management 30: 1087-1114.

$\mathrm{Xu}$ D, Shenkar O. 2002. Institutional distance and the multinational enterprise. Academy of Management Review 27: 608-618. 
Zaheer S. 1995. Overcoming the liability of foreignness. Academy of Management Journal 38: 341-363.

Zaheer S, Schomaker MS, Nachum L. 2012. Distance without direction: Restoring credibility to a much-loved construct. Journal of International Business Studies 43: 18-27.

Zhou N, Guillen MF. 2016. Categorizing the liability of foreignnes: Ownership, location, and internalization-specific dimensions. Global Strategy Journal 6: 309-329

Zhou N, Guillén MF. 2015. From home country to home base: A dynamic approach to the liability of foreignness. Strategic Management Journal 36: 907-917.

Zhu H, Chung C-N. 2014. Portfolios of political ties and business group strategy in emerging economies: Evidence from Taiwan. Administrative Science Quarterly 59: 599-638.

This article is protected by copyright. All rights reserved. 
Table 1. Calibration of sets

\begin{tabular}{|c|c|c|c|c|c|}
\hline Type & Variable & Measurement \& data source & $\begin{array}{c}\text { Calibration } \\
\text { method }\end{array}$ & $\begin{array}{l}\text { Fuzzy } \\
\text { sets }\end{array}$ & Note and references \\
\hline \multirow{2}{*}{$\begin{array}{l}\text { Institution } \\
\text {-based } \\
\text { view }\end{array}$} & $\begin{array}{l}\text { Home political } \\
\text { connections }\end{array}$ & $\begin{array}{l}\text { A 3-item scale }( \pm=0.83) \text { from Peng and Luo } \\
(2000)\end{array}$ & $5,4,3$ & 4 & $\begin{array}{l}\text { Standard Likert scale approach. See } \\
\text { Ragin (2008) }\end{array}$ \\
\hline & $\begin{array}{l}\text { Host political } \\
\text { connections }\end{array}$ & $\begin{array}{l}\text { A 3-item scale }( \pm=0.79) \text { from Peng and Luo } \\
(2000)\end{array}$ & $5,4,3$ & 4 & $\begin{array}{l}\text { Standard Likert scale approach. See } \\
\text { Ragin (2008) and Fiss (2011) }\end{array}$ \\
\hline $\begin{array}{l}\text { Industry- } \\
\text { based view }\end{array}$ & $\begin{array}{l}\text { Global environmental } \\
\text { munificence }\end{array}$ & $\begin{array}{l}\text { Calculated each year with moving three-year } \\
\text { windows data obtained from the UNIDO World }\end{array}$ & $\begin{array}{l}1.01,0.915 \\
0.82\end{array}$ & 3 & $\begin{array}{l}\text { Distribution-adjusted calibration } \\
\text { anchor points following Fiss (2011) }\end{array}$ \\
\hline
\end{tabular}

This article is protected by copyright. All rights reserved. 
Production Output database.

\begin{tabular}{|c|c|}
\hline $\begin{array}{l}\text { Global environmental } \\
\text { dynamism }\end{array}$ & $\begin{array}{l}1.106, \\
1.0835,1.061\end{array}$ \\
\hline
\end{tabular}

Table 2. Necessary conditions

\begin{tabular}{|c|c|c|c|c|}
\hline \multirow{2}{*}{ Causal configurational solutions } & \multicolumn{2}{|c|}{ High-distance investment } & \multicolumn{2}{|c|}{ Low-distance investment } \\
\hline & Consistency & Coverage & Consistency & Coverage \\
\hline \multicolumn{5}{|l|}{ Institution-based view } \\
\hline Home political connections & 0.66 & 0.46 & 0.76 & 0.75 \\
\hline Host political connections & 0.61 & 0.48 & 0.70 & 0.77 \\
\hline \multicolumn{5}{|l|}{ Resource-based view } \\
\hline$R \& D$ commitment & 0.56 & 0.44 & 0.67 & 0.75 \\
\hline Internationalization experience & 0.53 & 0.43 & 0.53 & 0.62 \\
\hline \multicolumn{5}{|l|}{ Industry-based view } \\
\hline Global environmental munificence & 0.66 & 0.43 & 0.70 & 0.64 \\
\hline Global environmental dynamism & 0.49 & 0.49 & 0.44 & 0.62 \\
\hline
\end{tabular}

Note: Necessary conditions are calculated with the fsQCA 2.5 software.

This article is protected by copyright. All rights reserved. 
This article is protected by copyright. All rights reserved. 
Table 3. Configurational solutions

\begin{tabular}{|c|c|c|c|c|c|c|c|c|}
\hline \multirow{2}{*}{ Strategy Tripod Framework } & \multicolumn{4}{|c|}{ High-distance investment } & \multicolumn{4}{|c|}{ Low-distance investment } \\
\hline & Solution 1a & Solution $1 \mathrm{~b}$ & Solution 2 & Solution 3 & Solution $4 \mathrm{a}$ & Solution $4 \mathrm{~b}$ & Solution 5 & Solution 6 \\
\hline \multicolumn{9}{|l|}{ Institution-based view } \\
\hline Home political connections & O & O & • & $\bullet$ & $\bullet$ & $\bullet$ & $\bullet$ & $\otimes$ \\
\hline Host political connections & $\otimes$ & $\bullet$ & O & $\bullet$ & O & O & & $\otimes$ \\
\hline \multicolumn{9}{|l|}{ Resource-based view } \\
\hline$R \& D$ commitment & $\otimes$ & $\otimes$ & $\otimes$ & O & 0 & O & O & $\otimes$ \\
\hline Internationalization experience & $\otimes$ & $\bullet$ & O & $\otimes$ & & & $\bullet$ & $\otimes$ \\
\hline \multicolumn{9}{|l|}{ Industry-based view } \\
\hline Global environmental munificence & 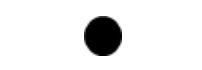 & O & $\otimes$ & $\otimes$ & $\otimes$ & • & $\otimes$ & C \\
\hline Global environmental dynamism & - & $\otimes$ & $\bullet$ & O & • & $\otimes$ & O & O \\
\hline Consistency & 0.89 & 0.86 & 0.91 & 0.87 & 0.84 & 0.85 & 0.85 & 0.86 \\
\hline Raw Coverage & 0.13 & 0.22 & 0.14 & 0.18 & 0.20 & 0.37 & 0.15 & 0.09 \\
\hline Unique Coverage & 0.04 & 0.12 & 0.04 & 0.08 & 0.06 & 0.10 & 0.02 & 0.03 \\
\hline Overall Solution Consistency & \multicolumn{4}{|c|}{0.82} & \multicolumn{4}{|c|}{0.83} \\
\hline
\end{tabular}

This article is protected by copyright. All rights reserved. 
Note: 1) Black circles indicate the presence of a condition, and circles with "X" indicate its absence. Large circles indicate core conditions; small ones, peripheral conditions. Blank spaces indicate "don't care". 2) Prime Implicants (High-distance investment) $=\sim R \& D$ Comm.*HomeTies * GEM (that is, appear in Solutions $1 \mathrm{a}+1 \mathrm{~b}$ ); Prime Implicants (Low-distance investment) $=R \& D$ Comm. *HostTies + GEM $* G E D * \sim$ HomeTies (that is, appear in Solutions $1 \mathrm{a}+1 \mathrm{~b}+3$ ). 


\section{University Library}

\section{- M M I N E R VA A gateway to Melbourne's research publications}

Minerva Access is the Institutional Repository of The University of Melbourne

Author/s:

Chen, L;Li, Y;Fan, D

Title:

How do emerging multinationals configure political connections across institutional contexts?

Date:

2018-08-01

Citation:

Chen, L., Li, Y. \& Fan, D. (2018). How do emerging multinationals configure political connections across institutional contexts?. GLOBAL STRATEGY JOURNAL, 8 (3), pp.447-470. https://doi.org/10.1002/gsj.1187.

Persistent Link:

http://hdl.handle.net/11343/294085 